\title{
Thrombosis and Risk Factors: A Comment
}

\section{Tromboz ve Risk Faktörleri: Bir Yorum}

\author{
Selami Koçak Toprak ${ }^{1}$, Yunus Kasım Terzi ${ }^{2}$, Feride Şahin ${ }^{2}$ \\ ${ }^{1}$ Baskent University, Department of Hematology, Ankara, Turkey \\ ${ }^{2}$ Baskent University, Department of Medical Genetics, Ankara, Turkey
}

\section{To the Editor,}

We read with great interest the recent publication by Akar related to thrombosis and risk factors, in which he reached in conclusion that in case of need only homocysteine (Hcy) levels should be routinely analyzed and not the 5, 10-methylenetetrahydrofolate reductase (MTHFR) $677 \mathrm{~T}$ polymorphism [1]. The methylation of Hcy to methionine is catalyzed by the MTHFR enzyme. As far as is known, genetic deficiency of MTHFR is one cause leading to increased plasma Hcy levels [2]. But, it should not be forgotten that Hcy rises in many acquired and genetic conditions (Table) [3]. There are three main indications for determining plasma total Hcy: (a) to diagnose homocystinuria; (b) to identify individuals with or at risk of developing cobalamin or folate deficiency; (c) to assess total Hcy as a risk factor for cardiovascular and other disorders [4]. There is an involved question in this point: Is increased plasma total Hcy level related to both venous and arterial occlusive disease? And, if is it true, are polymorphism and mutation of MTHFR directly playing a role to augment the level of Hcy for cardiovascular disease (CVD)? As reviewed elsewhere, moderately increased plasma Hcy is associated with venous and arterial occlusion [5]. Moreover, as it is known, the presence of MTHFR 677C $\rightarrow$ T polymorphism is a strong risk factor for increased plasma Hcy level but not for CVD [4]. In a metaanalysis including 11.162 CVD cases and 12.758 controls, with high Hcy levels in a state of low folate levels, the TT genotype was associated with a $16 \%$ increase in coronary heart disease risk [6]. Concordantly, previous studies had shown that the MTHFR
677C $\rightarrow$ T polymorphism is only associated with high Hcy levels or increased CVD risk in a setting of low folate status [6]. Hence, at higher dietary intakes of folate, the effect of the MTHFR $677 \mathrm{C} \rightarrow \mathrm{T}$ genotype has no adverse effect on plasma Hcy levels or on subsequent risk of CVD. The results support the hypothesis that impaired folate metabolism, resulting in high Hcy concentrations, plays a causal role in the occurrence of CVD. In view of cost effectiveness, do not investigate routinely MTHFR $677 \mathrm{C} \rightarrow \mathrm{T}$ polymorphism in the general or CVD population seems to be reasonable, but the other mutations of MTHFR could be still influential for high plasma Hcy levels.

In conclusion, even if some researchers contradict, provided that folate status is adequate, there is little clinical value of screening for MTHFR $677 \mathrm{C} \rightarrow \mathrm{T}$ genotype in the general population for prediction of venous and arterial occlusive disorders and high Hcy levels of course.

\section{Conflict of Interest Statement}

The authors of this paper have no conflicts of interest, including specific financial interests, relationships, and/ or affiliations relevant to the subject matter or materials included.

Address for Correspondence: Selami Koçak TOPRAK, M.D.,

Fevzi Çakmak Caddesi 5. Sokak No: 48 Kat: 1, 06490 Bahçelievler, Ankara, Turkey

Phone: +90 5326560206 E-mail: sktoprak@yahoo.com

Received/Geliş tarihi : July 18, 2011

Accepted/Kabul tarihi : July 22, 2011 
Table 1: Causes of Elevated Homocysteine Levels

\section{CAUSES}

Vitamin deficiency

Cobalamin deficiency

Folate deficiency

\section{Disease}

Renal failure

Posttransplantation

Hypothyroidism

Acute lymphocytic leukemia

Drugs and toxins

Alcohol abuse

Methotrexate and other antifols

Cyclosporine A

Nitrous oxide toxicity

\section{Genetic disorders}

Cystathionine $\beta$-synthase deficiency

Homozygous state

Heterozygous state

Hereditary disorders of cobalamin

Metabolism, transport, or absorption

Hereditary disorders of folate

Metabolism, transport, or absorption

Methylene tetrahydrofolate reductase

polymorphisms (homozygous C677T or

A1298C mutations)

Physiologic and lifestyle factors

Male sex

Mild

Aging

Coffee drinking

Smoking

\section{EFFECT}

Mild to severe

Mild to severe

Mild to moderate

Mild to moderate

Mild

Mild

Mild to severe

Mild to severe

Mild

Mild to severe

Severe

Mild or none

Mild to severe

Mild to severe

Mild or none

Modified from Carmel R. Megaloblastic Anemias: Disorders of Impaired DNA Synthesis. In: Greer JP, Foerster J, Rodgers GM, Paraskevas F, Glader B, Arber DA, Means RT Jr, eds. Wintrobe's Clinical Hematology. 12 ${ }^{\text {th }}$ ed. Philadelphia: Lippincott Williams E Wilkins, $2009: 1143-72$.

\section{References}

1. Akar N. Thrombosis and risk factors. Turk J Hematol 2010; 27:318-9.

2. Yilmaz H, Isbir S, Agachan B, Ergen A, Farsak B, Isbir T. C677T mutation of methylenetetrahydrofolate reductase gene and serum homocysteine levels in Turkish patients with coronary artery disease. Cell Biochem Funct. 2006; 24:87-90.

3. Carmel R. Megaloblastic Anemias: Disorders of Impaired DNA Synthesis. In: Greer JP, Foerster J, Rodgers GM, Paraskevas F, Glader B, Arber DA, Means RT Jr, eds. Wintrobe's Clinical Hematology. $12^{\text {th }}$ ed. Philadelphia: Lippincott Williams \& Wilkins, 2009: 1143-72.
4. Refsum H, Smith AD, Ueland PM, Nexo E, Clarke R, McPartlin J, Johnston C, Engbaek F, Schneede J, McPartlin C, Scott JM. Facts and recommendations about total homocysteine determinations: an expert opinion. Clin Chem 2004; 50(1):3-32.

5. Refsum H, Ueland PM, Nygård O, Vollset SE. Homocysteine and cardiovascular disease. Annu Rev Med. 1998; 49:31-62.

6. Klerk M, Verhoef P, Clarke R, Blom HJ, Kok FJ, Schouten EG; MTHFR Studies Collaboration Group. MTHFR 677C$\rightarrow \mathrm{T}$ polymorphism and risk of coronary heart disease: a meta-analysis. JAMA. 2002;288(16):2023-31. 


\section{Reply}

\section{Thrombosis and Risk Factors}

I read the comment of Toprak et al. on my letter to the Editor appeared in a recent issue of the journal with great interest [1]. They pointed a missing point in my letter and then focused on the effect of folate metabolism on homocysteine and metihelenetetrahydrofolate gene polymorphism at $677 \mathrm{C}$ to $\mathrm{T}$ extensively [1]

I would like to express my thanks to Toprak et al. giving a chance to explain my view on this matter once more.

As it is well known that there is a continuing debate on homocysteine metabolism, MTHFR SNP's and folate metabolism and there are several published reviews on this subject not reaching to a conclusion.

Recently we reported that MTHFR 677 T has an influence on Hcy levels in Turkish population. But also we found another possible MTHFR gene haplotype, which does not have an effect on Hcy levels [2].

Furthermore, there are also rare novel SNPs published within the MTHFR 677 region with an allele frequency of 1 in 3000-4000 sample, including MTHFR 678 C-A (Ala222Ala) in Turkish population [3-5] which may lead to erroneous technical reporting.

Since our first publication on homocysteine related gene polymorphisms in Turkish population in 1998 [6], and the others following the first paper, I reached to a conclusion that without determining homocysteine levels, analyzing MTHFR 677C-T solely at the DNA level is unnecessary, not cost effective and does not have any clinical value especially in Turkish population.

So, only homocysteine levels should be routinely analyzed and not the MTHFR 677 T SNP alone. If any cause of high homocysteine levels could not be found, then MTHFR $677 \mathrm{~T}$ analysis can be performed.

\section{References}

1. Akar N: Thrombosis and risk factors. Turk J Hematol 2010: 27 (4) : 318-319

2. Koç YL, Akar N: Single nucleotide polymorphisms that affect homocysteine levels in Turkish population. Clin Appl Thromb Hemost 2009; 15: 701-704

3. Lyon E: Discovering rare variants by use of melting temperature shifts seen in melting curve analysis. Clin Chem 2005; 51: 1331-1332

4. Erali M, Schmidt B, Lyon E, Wittwer C: Evaluation of electronic microarrays for genotyping factor $\mathrm{V}$, factor II, and MTHFR. Clin Chem 2003; 49: 732-739

5. Eğin Y, Akar N: First observation of MTHFR 678 C-A (Ala222Ala) single nucleotide polymorphism. Turk J Hematol 2011 (DOI: 10.5152/tjh.2011.45)

6. Akar N, Akar E, Misirlioğlu M, Avcu F, Yalçin A, Cin S: Search for genetic factors favoring thrombosis in Turkish population. Thromb Res 1998; 92 (2): 79-82

\section{Nejat Akar}

TOBB Economy and Technology University Hospital, Ankara, Turkey 